Gravenor, C. P. 1974. The Yarmouth drumlin field, Nova Scotia, Canada. Journal of Glaciology, Vol. 13, No. 67, p. $45^{-54}$.

Hollingworth, S. E. 1931. The glaciation of western Edenside and adjoining areas and the drumlins of Edenside and the Solway Basin. Quarterly Fournal of the Geological Society of London, Vol. 87, Pt. 2, p. 28I-359.

Rose, J., and Letzer, J. M. 1975. Drumlin measurements: a note on the reliability of data derived from topographic maps. Geological Magazine, Vol. 1 1 2, No. 4, p. 361-71.

Trenhaile, A. S. 1971. Drumlins: their distribution, orientation and morphology. Canadian Geographer, Vol. 15, No. 2, p. $113-26$.

\title{
SIR, Ice-movement direction from drumlin morphology: reply to comments by $W$. Everett
}

In Everett's letter she has correctly pointed out that the term "stoss" as it applies to the up-stream end of a drumlin is not synonymous with "steep". In describing the shape of a drumlin, however, it is important not only to determine the position of the steep end but also to consider the shape of the drumlin. For this reason, in my paper on the Yarmouth drumlin field (Gravenor, 1974, p. 5I) the word stoss is defined as follows: "unless otherwise specified, the word 'stoss' is used to mean the more steeply inclined wider end of the drumlin and the high point on the drumlin is closer to the steep end than the more shallowly inclined tapered 'tail' of the drumlin". In accordance with this definition, $55 \%$ of the drumlins in the Yarmouth field have stoss ends which are steeper and wider than the lee ends.

If drumlins are to be used to determine the direction of ice movement, it is important to define both the shape of the drumlins as well as the slope of the ends. This fact has been recognized by many researchers and excellent summaries on the importance of shape can be found in Embleton and King (1968, p. 322-27), Chorley (1959) and Doornkamp and King (1971, p. 298-304). In this regard, Doornkamp and King (1971, p. 302) have analysed the significance of the Chorley $K$-value and concluded "The variation of the $K$-values is a measure of the stress of the ice on the drumlin. The rounded end of the drumlin faces the direction from which the greatest pressure came".

It is unfortunate that Everett has stated "It is, as Gravenor states, generally taken for granted that the stoss is the steeper end and generally points towards the up-stream ice-movement direction". In fact, I said (Gravenor, I 974, p. 5I) "It is generally taken for granted that the stoss end of drumlins points towards the up-stream ice-movement direction". To the casual reader, these two statements may appear synonymous. It must be kept in mind, however, that my use of the word stoss in the paper on the Yarmouth drumlin field implies both shape and slope.

Nevertheless, it is worthwhile to examine the evidence that Everett has presented in an attempt to demonstrate that the steep end of drumlins is an unreliable indicator of ice-movement direction. From the published data referred to by Everett, it would appear that there is little evidence to suggest that a drumlin field exists where the bulk of the drumlins have a steeper lee end. For example, Everett has referred to Trenhaile's analysis of about 6 ooo-7 ooo drumlins in Ontario and states "Trenhaile's (1971) analysis of 6 0oo-7 ooo mapped drumlins in southern Ontario showed that $19 \%$ had lee steeper than stoss, and in $2 \%$ of these the lee was considerably steeper". This is a distortion of Trenhaile's findings as illustrated by the following quote from Trenhaile's paper: "One of the fundamental characteristics of the drumlin form is a stoss slope considerably steeper than the lee slope. An analysis was made to investigate both the order of these slopes and also any possible tendency towards the maintenance of a constant ratio between them. Data were obtained by field mapping using an Abney level for the localities on the six drumlin fields mentioned previously.

"The mean ratio for stoss-lee slopes was 1 : $28 / 1: 38$, although $19 \%$ of the sampled drumlins exhibited lee slopes steeper than the stoss slopes. There did not appear to be any evident pattern or spatial concentration of these atypical drumlins."

In summary, if drumlins are to be used for the determination of ice-movement direction, it is important to define not only the slope of the ends but also the shape. With regard to one of these parameters - slope-it has yet to be demonstrated conclusively that a drumlin field exists in which the bulk of the drumlins have steeper lee than stoss ends.

Department of Geology,

C. P. Gravenor

University of Windsor, Windsor, Ontario $\mathrm{NgB}_{3} \mathrm{P}_{4}$, Canada

${ }_{14}$ April 1975 


\section{REFERENCES}

Chorley, R. J. 1959. The shape of drumlins. Fournal of Glaciology, Vol. 3, No. 25, p. 339-44.

Doornkamp, J. C., and King, C. A. M. 1971. Numerical analysis in geomorphology: an introduction. London, Edward Arnold (Publishers) Ltd.

Embleton, C., and King, C. A. M. 1968. Glacial and periglacial geomorphology. [London], Edward Arnold (Publishers) Ltd.

Gravenor, C. P. 1974. The Yarmouth drumlin field, Nova Scotia, Canada. Journal of Glaciology, Vol. 13, No. 67, p. $45^{-54}$.

Trenhaile, A. S. 1971. Drumlins: their distribution, orientation and morphology. Canadian Geographer, Vol. 15, No. 2, p. $113-26$.

Sir, Morphology and development of medial moraines:
comments on the paper by R. J. Small and M. F. Clark

Whilst concurring with R. J. Small and M. J. Clark's (1974) analysis of the development of the medial moraines of the lower Glacier de Tsidjiore Nouve, I am a little disturbed that they should attribute a particular model of medial moraine development to Loomis's (1970) proposal for the form of that developed on Kaskawulsh Glacier, Yukon. Small and Clark write that "Loomis's explanation cannot be applied to the moraines of the Glacier de Tsidjiore Nouve without some modification". I suggest that Loomis's "model" be regarded with considerable trepidation - if, as Loomis (1970, p. I5) suggests, ablation and the development of an ice core constitute the major factors determining moraine morphology, the observation that the width of the medial moraine "remains relatively constant downvalley for many kilometers" seems a trifle odd. Certainly, beyond I $500 \mathrm{~m}$ down-glacier the seven distinct debris bands, of which the medial moraine is composed, lose their coherency-this is to be expected. However, the maintenance of a distinct debris-ice boundary, defining the lateral limits of the medial moraine, is difficult to equate with the supposed dominance of ablation. Moreover, coincidence of maximum elevation with minimum width (approximately $1.4 \mathrm{~km}$ down-glacier from the confluence of the two ice streams) would seem to suggest some other factor at work; one cannot avoid concluding that lateral compression between the two ice streams, not ablation, is the prime factor in the determination of moraine morphology. It is significant that the features described as being representative of the efficacy of ablation ("meltwater-associated features" (Loomis, 1970, p. 23)) and the 3 I ablation-stake sites, from which correlation between till thickness and mean daily ablation rates were derived, are all located at the confluence of the two ice streams where under no circumstances can the morphology be said to be representative of that developed on the median line down-glacier; here "the dominant topographic form is not a ridge but rather a large elliptical depression measuring $180 \times 130 \mathrm{~m}^{2}$ across the top and dropping $33 \mathrm{~m}$ to a conical bottom" (Loomis, 1970, p. 16).

Despite the existence of prominent topographic troughs on the two sides of the moraine band, control of the morphology of the moraine by lateral longitudinal melt-water streams is unlikely. Troughs need not necessarily be associated with such stream activity (though occupied for the greater part of their length by melt water); the quantity of debris moved by streams in the case of such a mechanism operating would, in the case of Kaskawulsh Glacier, where considerable quantities of debris could be expected to be removed by the thermal erosion activity of such water, undoubtedly lead to the initiation of differential ablation processes; marked topographical features in contrast to the present troughs could be expected to develop-for which, at present, no evidence is forthcoming. One cannot accept Loomis's (197o, p. 36) conclusion that "moraine relief is due entirely to differential ablation processes". This seems to be at odds with his later statement (p. $3^{8)}$ that "relief on the moraine increases downglacier as the moraine band narrows, the debris bands thicken and ablation rates decrease". Instead, it would appear that differential ablation is subsidiary to lateral compression between the two ice streams in the control of medial moraine morphology; pronounced longitudinally trending furrows in the thick basalt and shale bands near the centre of the medial moraine seem at odds with Loomis's later refutation of the efficacy of lateral compression in determining the primary dominant characteristics of medial moraine morphology, ablation only attaining this role in the immediate confluence zone; elsewhere its 